\title{
Switch from translation to RNA replication in a positive-stranded RNA virus
}

\author{
Andrea V. Gamamik and Raul Andino ${ }^{1}$ \\ Department of Microbiology and Immunology, University of California, San Francisco, California 94143-0414 USA
}

\begin{abstract}
In positive-stranded viruses, the genomic RNA serves as a template for both translation and RNA replication. Using poliovinus as a model, we examined the interaction between these two processes. We show that the RNA polymerase is unable to replicate RNA templates undergoing translation. We discovered that an RNA structure at the $5^{\prime}$ end of the viral genome, next to the intemal ribosomal entry site, carries signals that control both viral translation and RNA synthesis. The interaction of this RNA structure with the cellular factor PCBP up-regulates viral translation, while the binding of the viral protein $3 C D$ represses transiation and promotes negative-strand RNA synthesis. We propose that the interaction of 3CD with this RNA structure controls whether the genomic RNA is used for translation or RNA replication.
\end{abstract}

[Key Words: PCBP; positive-stranded virus; RN A replication; translational control; viral polymerase]

Received M arch 26, 1998; revised version accepted June 2, 1998.

The genomes of positive-stranded RNA viruses are important in at least three major processes: They act as mRNAs to direct the synthesis of viral proteins; they serve as templates for genome replication; and they are packaged along with structural proteins during viral assembly. The balance between these processes must be properly maintained to all ow efficient viral proliferation. Thus, once the viral RNA-dependent RNA polymerase and other essential proteins are synthesized, the genomic RN A must be used as a template for negative-strand RNA replication (Pogue et al. 1994). In principle, this creates a conflict between the translation and replication machinery: While the ribosomes are moving along the viral RNA in the 5' to $3^{\prime}$ direction, the polymerase initiates replication at the $3^{\prime}$ end of the same RNA and moves in the opposite direction as it synthesizes the complementary negative strand. It is not known whether the arrangement of ribosomes and polymerases on the RNA template allows both processes to occur simultaneously or whether translation and RNA replication interfere with each other.

To examine the interplay between translation and RNA replication, we have used poliovirus as a model, because both in vitro and in vivo systems are available to dissect the viral cycle (Molla et al. 1991; Barton and Flanegan 1993; Gamarnik and Andino 1996). Several ex-

${ }^{1}$ Corresponding author.

E-MAIL andino@cg. ucst.ech; FAX (415) 476-0939. periments have suggested that the highly conserved 5'untranslated region ( $5^{\prime} \cup T R$ ) of the poliovirus genome plays an important role in the regulation of both translation and RN A replication (Rohll et al. 1994). Two functional domains have been defined within this region: a short 5'-terminal element involved in RN A replication (Andino et al. 1990a, 1993; Harris et al . 1994; Roehl et al. 1997) and a longer element, termed the internal ribosomal entry site (IRES), involved in viral translation (Jang et al. 1988; Pelletier et al. 1988; Trono et al. 1988). It was originally thought that these two elements were independent; however, recent evidence suggests a functional overlap between them (Simoes and Sarnow 1991; Borman et al. 1994; Shiroki et al. 1995).

The regulatory function of the 5' UTR is probably me diated through its interactions with cellular and viral proteins (Ehrenfeld and Semler 1995; Jackson and Kaminski 1995; Belsham and Sonenberg 1996). The short 5'-terminal el ement of the 5' UTR folds into a cloverleaflike structure and forms a ribonucleoprotein complex with the cellular poly(C)-binding proteins 1 and 2 (referred to as PCBP in this report, but also known as hnRNP E or $\alpha C P$ ), and the viral protein $3 C D$, which is the uncleaved precursor of the viral protease $\left(3 C^{\text {pro }}\right)$ and polymerase (3D ${ }^{\text {pol }}$ ) (Gamarnik and Andino 1997; Parsley et al. 1997). Mutations that di srupt the formation of this ribonucleoprotein complex impair viral RN A replication (Andino et al. 1990a; Rohll et al. 1994). On the other hand, the IRES element enables ribosomes to internally enter the RN A without scanning from the 5' end Jang et 
al. 1988; Pelletier et al. 1988; Trono et al. 1988; Chen and Sarnow 1995). The mechanism by which the translation apparatus recognizes IRES sequences is unknown, but it has been proposed that many canonical initiation factors as well as other specific cellular proteins participate in the process (M eyer et al. 1995; Pestova et al. 1996). Currently, three noncanonical factors that bind to the IRES have been identified: polypyrimidine tract binding protein (PTB; Hellen et al. 1993); La autoantigen (M eerovitch et al. 1993); and PCBP (Blyn et al. 1996). Interestingly, PCBP appears to partici pate in both viral translation and RNA replication (Blyn et al. 1996, 1997; Gamarnik 1997; Parsley et al. 1997).

We have analyzed the interplay between poliovirus translation and RN A replication and the contribution of specific ribonucleoprotein complexes to the regulation of both processes. We show that the viral polymerase is unable to use the genomic RN A as a template for RN A synthesis while it is being used by translating ribosomes. We found that the cloverleaf RNA at the $5^{\prime}$ end of the viral genome is a bifunctional element involved in the regulation of both viral translation and RNA replication. The binding of the cellular protein PCBP to the cloverleaf enhances viral translation, while the binding of the viral protein $3 C D$ represses translation and facilitates negative-strand synthesis. Thus, we propose that overlapping translation and replication signals within the cloverleaf function as a strategy to coordinate the use of the genomic RNA for translation or RN A replication.

\section{Results}

Actively translating ribosomes inhibit the elongation activity of the poliovirus RNA polymerase $3 \mathrm{D}^{\mathrm{pol}}$

Poliovirus translation and negative-strand RNA synthesis use the same RN A template, but each process starts at different ends and proceeds in opposite directions. To investigate whether a poli ovirus RNA template can support translation and RNA replication simultaneously, we measured the elongation activity of a partially purified viral polymerase (3D ${ }^{\mathrm{pol}}$ ) added to a translation extract programmed with poliovirus RNA. A subgenomic poli ovi rus replicon (Polio-Luc) carrying a luciferase gene as a reporter was used as the template (Andino et al. 1993). Translation was measured by the amount of luciferase activity produced, and RN A synthesis was measured by the incorporation of [ $\left.{ }^{32} \mathrm{P}\right] \mathrm{A} M \mathrm{P}$ into the poliovirus RNA by elongation of a specific primer complementary to the $3^{\prime}$ UTR.

When the ribosomes were actively translating, [ $\left.{ }^{32} \mathrm{P}\right]$ U M P incorporation was almost undetectable (Fig. $1 A$ ), suggesting that the viral polymerase was unable to synthesize RNA. In contrast, when translation was inhibited by cycloheximide, which stalled the ribosomes at the beginning of the coding region, $3 \mathrm{D}^{\text {pol }}$ was able to incorporate [32P]UMP into RNA (Fig. 1B). These results indicate that poliovirus RNA synthesis occurs only when the RNA is free of translating ribosomes. Therefore, the virus should have a mechanism to clear the
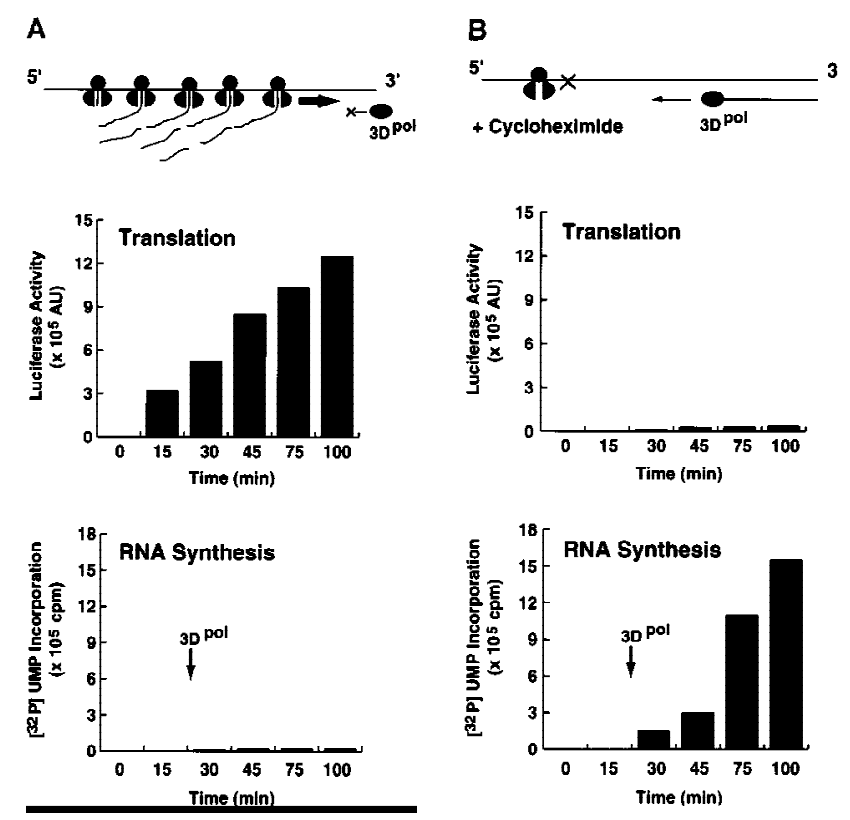

Figure 1. Poliovirus translation inhibits $3 D^{\text {pol }}$ RNA el ongation activity. (A) A poliovirus replicon (Polio-Luc, Fig. 2A) was in vitro-translated in a translation system supplemented with purified poliovirus 3D polymerase (3D $\left.{ }^{\mathrm{pol}}\right)$. Translation (top) was determined by the amount of luciferase activity produced and was expressed as arbitrary units (AU). RN A synthesis (bottom) was measured by [ $\left.{ }^{32} \mathrm{P}\right] \cup \mathrm{M} P$ incorporation into an acid-insoluble fraction. (B) The same experiment described in A was performed in the presence of cycloheximide $(100 \mu \mathrm{g} / \mu \mathrm{l})$.

genome of ribosomes to produce a viral RN A competent for RNA replication.

Poliovirus-infected extracts contain an activity that inhibits viral translation

It is possible that during the course of infection the virus induces activities that control initiation of translation when RN A replication must begin. To examine this possibility, we analyzed the effect of extracts from poliovirus-infected cells on translation of a Polio-Luc RN A in Xenopus oocytes. We have showed previously that Xenopus oocytes can support poliovirus replication (Gamarnik and Andino 1996). Microinjection of poliovirus RN A together with a cytoplasmic HeLa cell extract initiates a replication cycle, in which viral transl ation, genome replication, and assembly cl osel y resemble the processes observed in mammalian cells.

Two types of RNA were microinjected into Xenopus oocytes: a poliovirus replicon (Polio-Luc) in which the sequences encoding capsid proteins were replaced by a luciferase reporter gene; and, as a control, a capped RN A encoding luciferase (C ap-Luc) that included the $5^{\prime}$ and $3^{\prime}$ UTRs of the $\beta$-globin mRNA (Fig. 2A). Each construct was coinjected with cytoplasmic fractions obtained from either uninfected or poliovirus-infected HeLa cells. It is known that poliovirus induces the selective inhibition of host cell translation, which has been associated with the cleavage of the initiation factor elF-4G by the viral pro- 


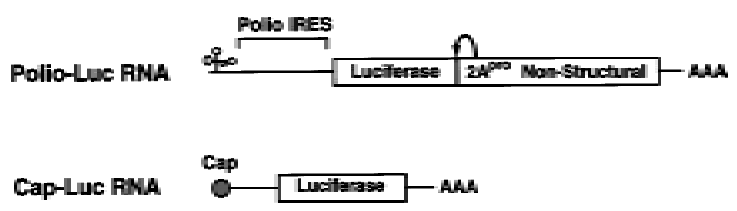

B

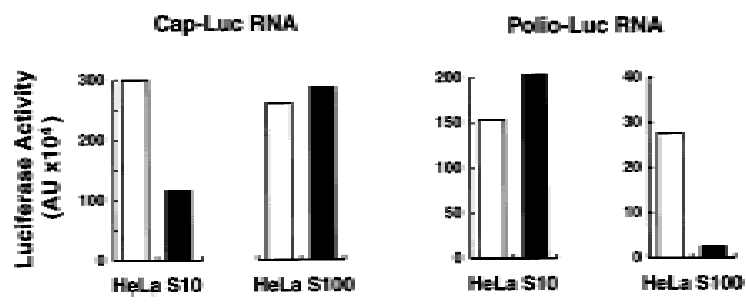

C

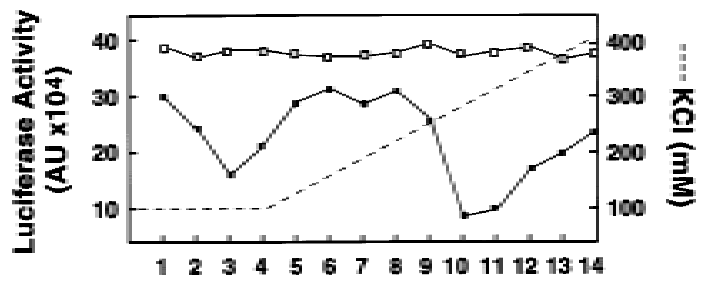

D

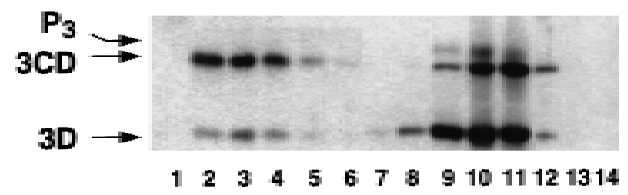

tease $2 A^{\text {pro }}$ (for review, see $M$ athews 1996). As expected, crude S10 extracts from infected HeLa cells strongly inhi bited cap-dependent translation, but stimulated PolioLuc RNA translation by $30 \%$ (Fig. 2B). Interestingly, a further purified fraction obtained from poliovirus-infected cells (HeLa S100) contained an activity that strongly inhibited viral translation (Fig. 2B, right). This negative effect was specific for poliovirus cap-independent translation, because Cap-Luc RN A was efficiently translated after coinjection with either infected or uninfected S100 HeLa cell extracts (Fig. 2B, left).

Because the inhibitory effect on translation was observed only with injection of infected extracts, the inhibitory activity must involve either a viral factor or a virally modified cellular factor. To characterize this activity further, we fractionated the infected S100 extract by chromatography on a HiTrap SP column. Part of the inhibitory activity was recovered in the flowthrough, while a larger part was retained in the col umn and el uted at $250 \mathrm{~mm} \mathrm{KCl}$ (Fig. 2C). As observed with the total extract, microinjection of the fractions had no effect on translation of Cap-Luc RNA (Fig. 2C). Then, we analyzed whether the fractions showing inhibitory activity
Figure 2. Poliovirus-infected cell extracts contain an activity that specifically inhibits poliovirus translation. (A) Schematic representation of the chimeric poliovirus luciferase RN A (Polio-Luc) and capped luciferase RNA (Cap-Luc). In Polio-Luc, the coding region of the poliovirus capsid proteins was replaced by the luciferase reporter gene, and a cleavage site for $2 A^{\text {pro }}$ has been introduced between luciferase and 2A pro (represented by the arrow). The Cap-Luc RNA consists of the luciferase gene flanked by the $5^{\prime}$ and $3^{\prime}$ uncoding regions of the $\beta$-globin mRN A. (B) Microinjection of infected S100 HeLa cell extract into Xenopus oocytes specifically inhibits poliovirus cap-independent translation. Polio-Luc or Cap-Luc RNA was injected into oocytes together with uninfected (open bars) or poliovirusinfected S10 or S100 HeLa cell fractions (solid bars) as indicated in each case. Luciferase activity was determined in oocytes after $3 \mathrm{hr}$ of incubation at $22^{\circ} \mathrm{C}$ and expressed in arbitrary units (AU). (C) Elution profile of the translation inhibitory activity after ion-exchange chromatography. Infected S100 HeLa cell extract was loaded onto a HiT rap SP column (Pharmacia) and eluted with a $\mathrm{KCl}$ gradient, as indicated at right. The translation inhibitory activity was determined by coinjection of $20 \mathrm{nl}$ of each fraction (1-14) together with $5 \mathrm{nl}$ of HeLa S10 (to provide the cellular factor essential for poliovirus translation in oocytes, PTF) and 20 ng of Polio-Luc RN A ( $\mathbf{\square}$ ) or Cap-Luc RN A ( $\square$ ) into oocytes. Luciferase activity was determined in oocyte extracts after $3 \mathrm{hr}$ of incubation at $22^{\circ} \mathrm{C}$ and expressed in AU. (D) Viral proteins $3 \mathrm{D}^{\mathrm{pol}}, 3 \mathrm{CD}$, and $\mathrm{P} 3$ copurified with the viral translation inhibitory activity. Western blot analysis of fractions 1-14 eluted from the HiT rap SP column is shown. Two microliters of each fraction was resolved in a $10 \%$ SDS-polyacrylamide gel, transferred to nitrocelluose membrane, and probed with specific anti-3CD antibodies. The electrophoretic mobility of P3, 3CD, and $3 \mathrm{D}$ is indicated at left.

contained any viral protein. Western blot analysis revealed that the inhibitory activity copurified with the viral proteins $3 D^{\text {pol }}, 3 C D$, and partially with their precursor P3 (Fig. 2D), but not with other viral proteins (data not shown). Interestingly, $3 \mathrm{D}^{\mathrm{pol}}$ is the RNA-dependent RNA polymerase that is synthesized as a fusion protein with $3 C^{\text {pro }}$, a protease that also binds to specific sequences of the viral 5' UTR (Andino et al. 1990b, 1993).

The viral protein $3 C D$ represses poliovirus translation

To determine whether any of the 3D-contai ning proteins were responsible for the inhibitory effect on translation, we took advantage of the RNA-binding properties of $3 C^{\text {pro. }}$. Affinity chromatography with an immobilized RNA was used to deplete 3CD from the most active column fractions. The treated fraction retained most of the $3 D^{\text {pol }}$ protein but $<10 \%$ of the original amounts of 3CD and P3 (Fig. 3A, left). Significantly, the depleted fraction lacked the ability to repress viral translation when microinjected into Xenopus oocytes (Fig. 3A, right), suggesting that the $3 C^{\text {pro }}$ domain is required for this inhibitory activity. 
A
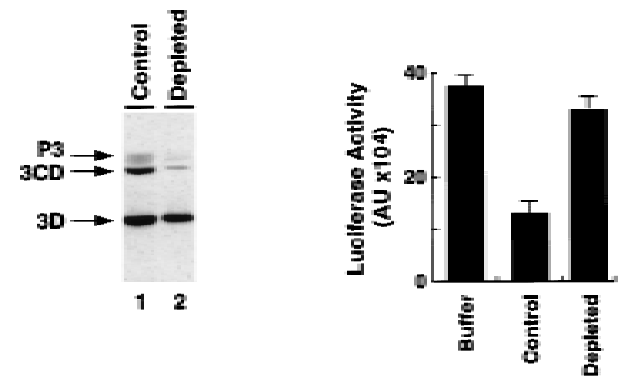

B
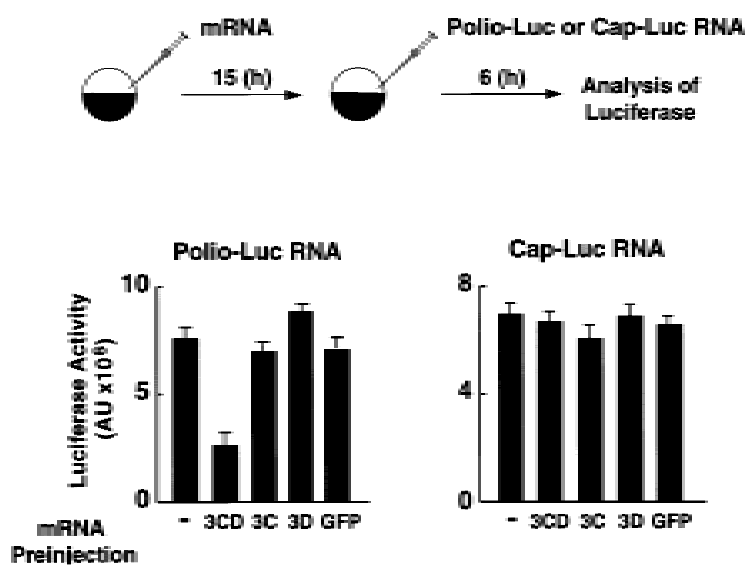

Figure 3. The polymerase-protease precursor, $3 C D$, represses viral translation. (A) Depletion of 3CD from infected cell extracts correlates with loss of translation inhibition. The viral protein $3 C D$ was depleted from a partially purified infected HeLa fraction by affinity chromatography by use of an immobilized cloverleaf RN A (see M aterials and M ethods). (Left) Two microliters of 3CD-depleted extract (lane 2) and $2 \mu \mathrm{l}$ of a nondepleted control (lane 1 ) were subjected to Western bl ot analysis as described for Fig. 2C. (Right) Luciferase activity was determined in oocyte extracts $3 \mathrm{hr}$ after coinjection of Polio-Luc RNA with buffer, nondepleted control, or 3CD-depleted fractions as indicated in the bottom. (B) Overexpression of mutated 3CD (GIn-182 $\rightarrow$ Asn) in Xenopus oocytes inhibits poliovirus translation. (Top) Schematic diagram of the microinjection protocol. Oocytes were injected with $4 \mathrm{ng}$ of a capped RN A encoding for $3 C D, 3 C, 3 D$, or an unrelated RNA encoding GFP, and incubated at $17^{\circ} \mathrm{C}$ for $15 \mathrm{hr}$. Then, oocytes were microinjected a second time with 40 ng of Polio-Luc or Cap-Luc RN A. Luciferase expression in oocytes was measured by enzymatic activity $6 \mathrm{hr}$ after the second microinjection. Translation of Polio-Luc and Cap-Luc RN A was determined in oocytes that were preinjected with the mRN As or with buffer control $(-)$ as indicated at the bottom. Luciferase activity was expressed in arbitrary units $(A U)$.

We next determined whether $3 C D$ al one is sufficient to inhibit poliovirus translation. Four different proteins were expressed in Xenopus oocytes by preinjection of synthetic mRN As encoding the corresponding polypeptide: $3 C^{\text {pro }}, 3 D^{\text {pol }}$, a mutated $3 C D$ with an alteration at the cleavage site between $3 C^{\text {pro }}$ and $3 D^{\text {pol }}$ (GIn 182 to
Asn; Andino et al. 1993) that completely eliminates the autoproteolytic processing of the precursor 3CD; and an unrelated mRNA control encoding green fluorescent protein (GFP). Because expression of each protein reached the highest level between 10 and $15 \mathrm{hr}$ after injection, as monitored by Western blot analysis (data not shown), we injected Polio-Luc and Cap-Luc RN A 15 hr after injection of the mRNAs. While translation of Cap-Luc RN A proceeded normally in oocytes expressing 3CD (Fig. 3B, right), the translation of Polio-LuC RNA was inhibited by $60 \%$ (Fig. 3B, left). In contrast, none of the other prei ijections (3C, 3D, or GFP) had a significant effect on luciferase expressed by either Cap-Luc or Polio-Luc. Taken together, these results strongly suggest that the protease-polymerase fusi on $3 C D$ specifical ly inhibits viral cap-independent translation.

\section{The cloverleaf RNA controls poliovirus translation}

Because $3 C D$ is a known RNA-binding protein that binds to the cloverl eaf domain of the poliovirus $5^{\prime}$ UTR, we reasoned that $3 C D$ might exert its inhibitory effect by interacting with this or other regulatory RNA elements. We have demonstrated previously that $3 C D$ interacts specifical ly with the isolated cloverleaf to form a ternary ribonucleoprotein complex with a ribosome-associated cellular factor, PCBP (Andino et al. 1993; Gamarnik and Andino 1997; Parsley et al. 1997); but it was unknown whether $3 C D$ interacts with other regi ons of the viral RN A. To examine other possible sites of 3CD interactions with the viral UTRs, we performed mobility-shift experiments using several defined domains of the poliovirus RNA as probes. The results obtained indicated that 3CD binds only to the cloverleaf RNA (A. Gamarnik and R. Andino, in prep.).

To charaterize further the regulatory role of $3 C D$ and the cloverleaf, we examined whether the cl overleaf RN A directly participates in poliovirus translation. We have shown previously that disrupting the interaction of $3 C D$ with the cloverleaf RNA affects positive-strand RNA synthesis without impai ring viral translation (Andino et al. 1993). In that previous study, we observed a small enhancement of translation for mutants in which $3 C D$ was unable to interact with the cloverleaf RNA. Those differences were originally interpreted as insignificant. However, because the results presented here strongly implicate $3 C D$ in translational control, and because it has been shown previously that PCBP is a positive regulator of poliovirus translation (Gamarnik and Andino 1997; Parsley et al. 1997), we reexamined the importance of these RN A-protein interactions in the translation process. To this end, we designed Polio-Luc constructs containing cl overleaf mutations that specifically disrupted the binding of either 3 CD or PCBP.

The polymerase precursor $3 C D$ binds to stem-loop $D$ of the cloverleaf RNA, whereas PCBP specifically interacts with stem-loop B (Fig. 4A) (Gamarnik and Andino 1997; Parsley et al. 1997). Three types of mutant RN As were constructed: one with the entire cl overl eaf deleted $(\Delta C L)$; a second type in which the interaction of the RN A 


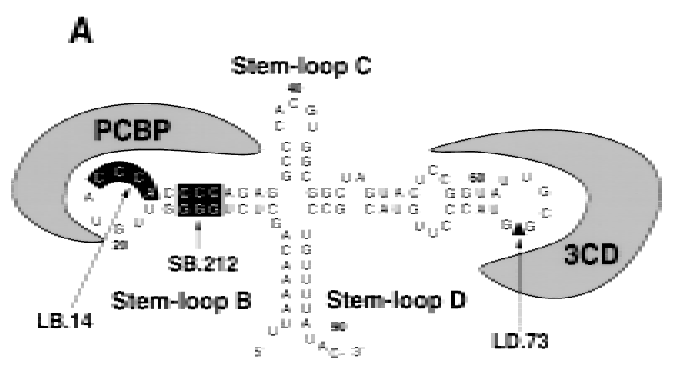

B

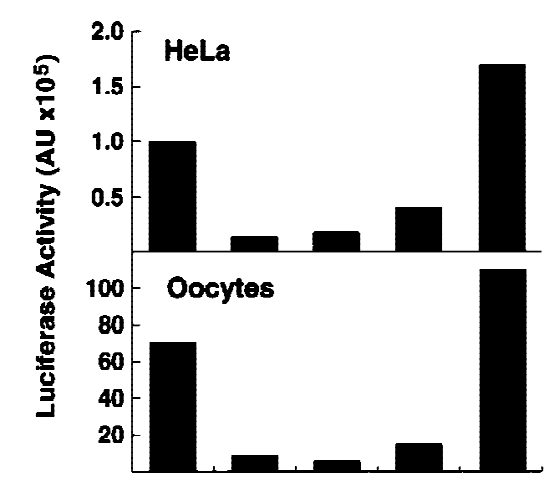

\begin{tabular}{llllll} 
Pollo-LUC WT & WCL & LB.14 & SB.212 & LD.73 \\
\hline
\end{tabular}

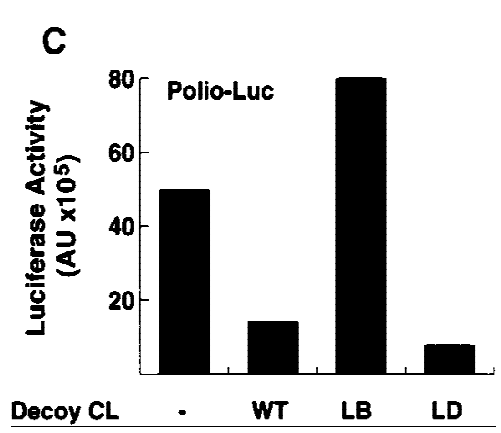

Figure 4. The cloverleaf structure formed at the $5^{\prime}$ end of the viral genome controls viral translation. (A) Schematic representation of the ribonucleoprotein complex formed around the cloverleaf RNA. The predicted cloverleaf structure is composed of stem-loop B (nucleotides 10-34), stem-loop C (nucleotides 35-45), and stem-loop D (nucleotides 51-78). Viral factor $3 C D$ and cellular protein PCBP are shown interacting with their specific target sequences. The locations of the mutations introduced into the cloverleaf structure of the Polio-Luc RNAs are indicated by arrows: LB.14 (nucleotides 23-26, CCCA, were deleted in loop B); SB.212 (nucleotides 14-16, GGG, and nucleotides 28-30, CCC, were replaced with AAA and UUU, respectively, which maintain the stem B structure); and LD.73 (nucleotides GUAC were inserted in position 70 of loop D). (B) Luciferase activity produced by Polio-LuC constructs carrying wild-type or mutated cloverleaf structures. In vitro-transcribed PolioLuc RN As were either transfected into HeLa cells (top) or microinjected into Xenopus oocytes (bottom). The RNAs are indicated as WT (wild-type), $\triangle \mathrm{CL}$ (cloverleaf-deleted), LB.14 (loop B muted), SB.212 (stem B mutated), and LD.73 (loop D mutant). Luciferase activity was measured in HeLa cell extracts $2 \mathrm{hr}$ after el ectroporation and in oocyte extracts $10 \mathrm{hr}$ after injection, and expressed in arbitrary units (AU). (C) Microinjection of decoy cloverleaf RN As into Xenopus oocytes interferes with poliovirus translation. Wildtype Polio-Luc RN A was coinjected with buffer (-), $30 \mathrm{ng}$ of wild-type cloverleaf (WT), or 30 ng of mutant cloverleaf decoys (LB, nucleotides C23 to A26 deleted, or LD, nucleotides GUAC inserted in position 70). Luciferase activity was determined in oocyte extracts $10 \mathrm{hr}$ after injection.

with PCBP was either abolished by a 4-nucleotide deletion at the top of stem-loop B (LB.14) or reduced by a substitution in stem B (SB.212); and a third typein which the interaction of $3 C D$ with the RNA was partially disrupted by a 4-nucleotide insertion at the top of stemloop D (LD.73).

Translation efficiencies of wild-type and mutant Polio-Luc RN As were eval uated by measurement of luciferase activity produced as a function of time after transfection into HeLa cells or microinjection into Xenopus oocytes. These experiments were carried out under conditions in which luciferase activity was produced only by the input RNA. For the transfections into HeLa cells, luciferase activity was measured prior to RNA replication (A ndino et al. 1993), while in Xenopus oocytes, the amount of newly synthesized RNA was negligible in comparison to the injected RNA. The Polio-Luc RN A construct with the deleted cloverleaf $(\triangle C L)$ or with the mutation that abolished PCBP binding (LB.14) translated at $10 \%$ of the efficiency of wild type (Fig. 4B). The PolioLuc mutant with reduced binding to PCBP (SB. 212) translated at $40 \%$ of the efficiency of wild type. In contrast, the mutant with a deficiency in 3CD-cloverleaf interaction (LD.73) showed a substantial increase in viral translation (Fig. 4B). These results suggest that the binding site for PCBP within the cloverleaf structure is necessary for efficient viral translation. The involvement of the cloverleaf in translation was first postulated by Simoes and Sarnow (1991). In agreement with our results, these authors reported a poliovirus mutant with a 6nucleotide insertion at the top of stem-loop B, which resulted in a significant decrease in viral translation ( $\mathrm{Si}$ moes and Sarnow 1991). Furthermore, the increase of translation that we observed with LD.73 suggests that the inhibitory effect of $3 C D$ may involve its binding to the cloverleaf structure.

The role of $3 C D$ and PCBP in viral translation was evaluated further by competition experiments. We microinjected an excess of wild-type or mutated cloverleaf competitor together with the Polio-Luc reporter construct into Xenopus oocytes. We hypothesized that the free cloverleaf RNAs would interact with $3 C D$ and/or PCBP, sequestering the proteins from their normal function in translation. Indeed, when wild-type or stem-loop D mutant RNA decoys were coinjected with Polio-Luc, we observed an $80 \%$ inhibition of luciferase production (Fig. 4C). Because both decoys have intact PCBP-binding sites, this result suggests further that PCBP is required for efficient translation. In contrast, a cloverleaf competitor carrying the stem-loop $\mathrm{B}$ mutation (unable to bind PCBP but fully capable of binding $3 C D$ ) did not decrease but rather stimulated viral translation, presumably by titrating out $3 C D$ expressed by the Polio-Luc RNA. Taken together, these results indicate that the 
cloverleaf is a bifunctional element: In addition to its previously described function in RNA replication, it plays a central role in the regulation of poliovirus translation.

Synthesis of poliovirus negative-strand RNA in Xenopus oocytes

In previous studies, we analyzed the rol e of the cl overl eaf structure in RN A synthesis using mutants that had defects in 3CD binding to the cloverleaf. These mutations yiel ded viable viruses that displayed a general reduction of RNA accumulation, in which the levels of positivestrand RN A seemed to be more compromised than those of negative strand (Andino et al. 1990a). Furthermore, we found that viruses carrying mutations in the cloverleaf that completely abrogated $3 C D$ binding were unable to synthesize detectable quantities of either negative- or positive-strand RNA in HeLa cells (R. Andino, unpubl.). For these mutants, it was difficult to determine whether the synthesis of negative strand was affected directly by the disruption of the ternary complex or indirectly as a consequence of the lack of positive-strand synthesis. To overcome this problem, we developed a novel method using Xenopus oocytes that permits the analysis of negative-strand synthesis in the absence of positive-strand amplification. Briefly, ${ }^{32} \mathrm{P}$-labeled synthetic poliovirus RNA is microinjected into Xenopus oocytes, and the fate of the labeled positive-strand RNA is analyzed by native agarose gel electrophoresis. During viral replication three classes of RNAs accumulate in infected cells: single-stranded RN A (ssRNA), replicative intermediate (RI), and the fully double-stranded replicative form (RF) (for review, see Johnson et al. 1995). Because RI and RF are composed of positive as well as negativestrand RNAs, the conversion of the input ${ }^{32} \mathrm{P}$-labeled RN A into these forms can be taken as an indicator of negative strand synthesis.

When ${ }^{32} \mathrm{P}$-labeled positive-strand wild-type RNA was microinjected into oocytes, the input molecule was converted to a DNase and RN ase A-resistant RNA form with identical mobility to the RF obtained from HeLa cell crude replication complexes (Fig. 5A, lanes 5,6). Although the ${ }^{32} \mathrm{P}$-labeled input RNA was degraded over time, the amount of mononucleosides released is not sufficient to yield detectable newly synthesized ssRN A (Gamarnik and Andino 1996, and data not shown). Thus, the label ed RN A observed at later time points is presumably composed of the input ${ }^{32} \mathrm{P}$-labeled positive-strand and newly synthesized unlabel ed negative-strand RN A.

Next, we studied whether the newly synthesized double-stranded RN A in fact contains authentic poliovirus negative strand. RN A obtained from a large number of oocytes microinjected with unlabeled positive-strand RNA or from virus-infected HeLa cells was RN ase and DN ase treated and analyzed by Northern blotting after denaturing agarose gel el ectrophoresis. Both samples displayed a single RNA band of identical electrophoretic
Figure 5. Synthesis of viral negative-strand RN A in Xenopus oocytes. (A) Oocytes were microinjected with in vitro-transcribed ${ }^{32} \mathrm{P}$-labeled poliovirus RN A together with HeLa S10 extracts (Gamarnik and Andino 1996), and the conversion of the input RN A into a double-stranded form was analyzed as a function of the time in $1 \%$ native agarose gels electrophoresis, as indicated on the top. For comparison, ${ }^{32} \mathrm{P}$-labeled poliovirus RNA was synthesized in crude replication complexes (CRC) obtained from poliovirus-infected HeLa cells (lane 1). Single stranded viral RNA (SSRNA) and the double stranded replicative form (RF), are indicated at left. (B) N orthern bl ot analysis confirms that the oocytes produce negative-strand RNA. Oocyte extracts obtained from 200 oocytes at $20 \mathrm{hr}$ after microinjection of unlabeled viral RNA were used to detect newly synthesized negative-strand RNA (lane 2). DN aseand RN ase-treated samples were extracted with phenol-chloroform, ethanol precipitated, and resolved under denaturing conditions through $1 \%$ agarose gel electrophoresis. Then, RN A was transferred to a nyIon filter, and hybridized with a specific probe complementary to the viral negative strand. As a control, infected Hela extracts treated in similar conditions was analyzed (lane 1). (C) The replicative form synthesized in oocytes contains a covalently linked Vpg molecule. Oocytes injected with ${ }^{32} \mathrm{P}-\mathrm{la}$ beled poliovirus RNA were lysed at 0 and $20 \mathrm{hr}$ post-injection (as described in Materials and M ethods), immunoprecipitated with anti-Vpg antibodies ( $\alpha$-Vpg) or preimmune sera (Preimm.), and analyzed in 1\% native agarose gel (lanes 1-3). Total RN A from oocytes injected with ${ }^{32} \mathrm{P}$-label ed poliovirus RN A obtained $20 \mathrm{hr}$ after incubation (lane 4) and ${ }^{32} \mathrm{P}$-label ed RN A synthesized in crude replication complexes obtained from infected HeLa cells (lanes 5) are shown.

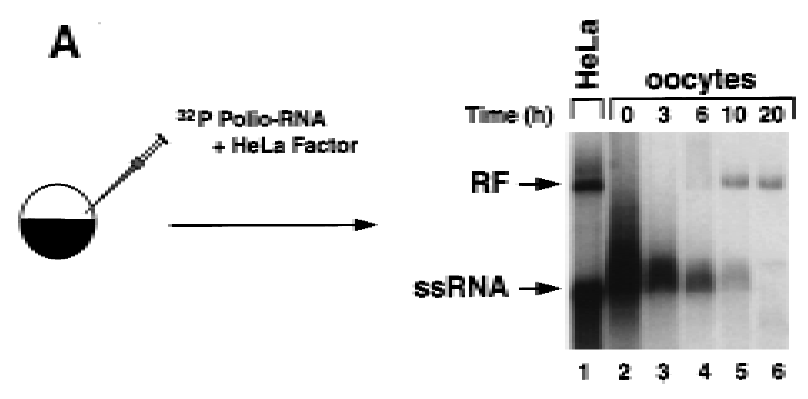

B

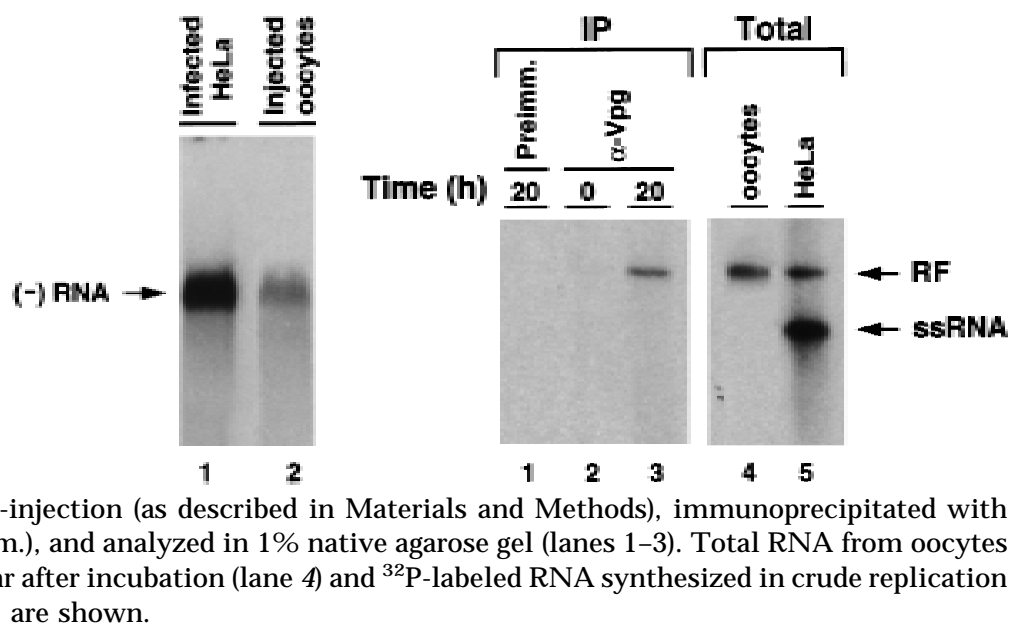


mobility that hybridized specifically with a poliovirus positive-strand RNA probe (Fig. 5B).

To characterize further the RF RNA produced in oocytes, we examined whether this molecule contains Vpg, a genomelinked viral peptide. During RNA replication, $\checkmark p g$ is added to the $5^{\prime}$ end of the growing RN A chains at a very early stage, possibly as a primer of RNA synthesis. This protein is found in both positive- and negativestrand RNAs, suggesting that a similar mechanism is responsible for initiation of synthesis of both strands (Flanegan et al. 1977; Pettersson et al. 1978). Therefore, in infected cells, the RF RN A contains Vpg linked to the 5' end of both strands. However, the RF synthesi zed after one round of replication in oocytes should onl y carry Vpg attached to the $5^{\prime}$ end of the negative strand, because the positive strand is the product of T7 RNA polymerase transcription. As expected, phenol- and SDS-treated double-stranded RNA produced in oocytes was immunoprecipitated by antibodies directed against $\mathrm{Vpg}$ but not by pre-immune sera (Fig. 5C, lanes 1,3). In addition, antiVpg antibodies did not precipitate ${ }^{32} \mathrm{P}$-labeled RNA at early time points before double-stranded RNA was observed (Fig. 5C, lane 2), showing that the input SsRN A cannot be precipitated by anti-Vpg antibodies. These results indicate that the double-stranded RNA formed in oocytes contains negative-strand RN A coval ently linked to $\mathrm{Vpg}$, which closely resembles that produced in HeLa infected cells.

Binding of $3 C D$ to the cloverleaf RNA is required for negative-strand RNA synthesis

Using the method described in the previous section, we determined whether negative-strand RNA synthesis is affected by mutations that completely disrupt 3CD interaction with the cloverleaf. Two mutants were used (schematically represented in Fig. 6A), one in which the cloverleaf structure was modified by al tering 2 bp at the top of stem-loop D (Polio-315), and the other with an alteration in the putative RN A-binding domain of $3 C D$, which was unable to bind to the cloverleaf RNA but displayed normal proteolysis (Polio-181). These mutants yiel ded no virus after transfection into HeLa cells, indicating that the mutation severely compromised viral replication.

We first studied the ability of these mutants to direct translation in the oocyte system. The amount of luciferase activity produced by the mutants during the first $2 \mathrm{hr}$ postinjection was similar to that of wild type (Fig. 6B). In contrast, at 4 and $8 \mathrm{hr}$ post-injection, both mutated RN As were translated at higher levels than the wild-type RNA, once again indicating that the inability of $3 C D$ to

A

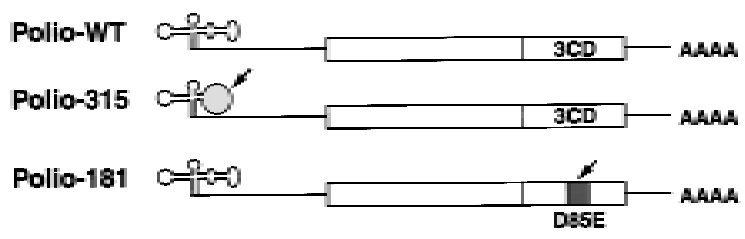

B

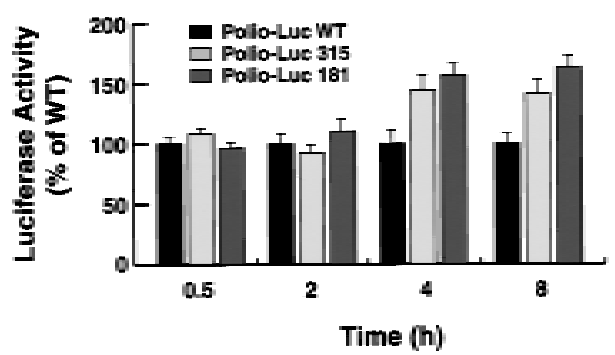

C

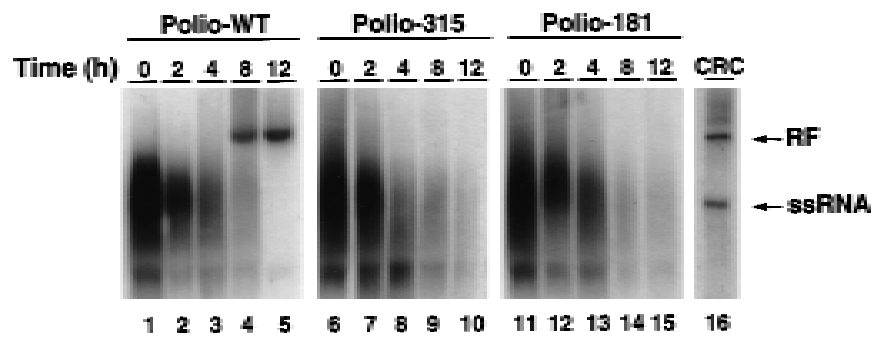

Figure 6. The interaction between $3 C D$ and the cloverleaf RNA is required for negative strand RNA synthesis. (A) Schematic representation of wild-type poliovirus genome (Polio-WT), a mutant in the cloverleaf structure in which two Us in positions 60 and 68 were replaced by $C$ s to disrupt stem-loop D (Polio-315), and a mutant in 3CD-coding sequence in which the Asp-85 was replaced by Glu, which abrogates RN A binding (Polio-181). (B) Disrupting 3CD-cloverleaf interaction increases viral translation. Oocytes were microinjected with Polio-Luc WT (black bars), Polio-Luc 315 (white bars), or Polio-Luc 181 (gray bars) RN As and incubated at $22^{\circ} \mathrm{C}$. Cytoplasmic extracts were obtained, and luciferase activity was measured at the indicated times $(0.5,2,4$, and $8 \mathrm{hr}$ ). (C) Disruption of 3CD-cloverleaf interaction abolishes negative-strand RN A synthesis. Oocytes were microinjected with ${ }^{32} \mathrm{P}$-label ed Polio-WT (lanes 1-5), mutant Polio-315 (lanes 6-10), or mutant Polio-181 (lanes 11-15) and incubated at $30^{\circ} \mathrm{C}$. Total RN A was extracted at $0,2,4,8$, and $12 \mathrm{hr}$, and analyzed on $1 \%$ agarose gels. For comparison, ${ }^{32} \mathrm{P}-$-labeled poliovirus RNA was synthesized in crude replication complexes (CRC) obtained from poliovirus-infected HeLa cells (lane 16). Double-stranded (ds) replicative form and single-stranded (ss) poliovirus RNAs are indicated. 
interact with the cloverleaf structure results in an increase in protein synthesis.

We next examined negative-strand RNA synthesis in both wild type and mutants. When ${ }^{32} \mathrm{P}$-labeled wild-type RNA was microinjected into oocytes, the input molecules were readily converted to an RF form (Fig. 6C, Ianes 4,5). However, the RN As corresponding to the mutants that were defective in $3 C D$ binding to the cloverleaf were unable to synthesize RF (lanes 9,10,14,15), indicating that the interaction of $3 C D$ with the cloverleaf RNA not only down-regulates viral translation but is essential for negative-strand RNA synthesis.

\section{Discussion}

The replication of positive-stranded RNA viruses presents an unresolved conundrum: How is the negativestrand RNA synthesized in the face of a wave of translating ribosomes moving in the opposite direction? We have studied this problem in the context of poliovirus replication and have found that actively transl ating ribosomes prevent RN A synthesis. Because each molecule of genomic RN A must be used for translation prior to RN A replication (Kuge et al. 1986; Collis et al. 1992; N ovak and Kirkegaard 1994), the virus should have a mechanism to down-regulate translation to begin RNA synthesis. We found that an RNA el ement at the $5^{\prime}$ end of the viral genome, the cloverleaf RNA, contains overlapping signals for translation and RNA replication. The binding of the cellular protein PCBP to this RNA greatly enhances viral translation, while the binding of the viral polymerase precursor, $3 C D$, represses viral translation and promotes the synthesis of negative-strand RNA. We propose that these RN A-protein interactions determine the switch from translation to RNA replication.

Role of the cloverleaf RNA in translation and RNA replication

The results described here suggest that the cloverleaf coordinates the use of the viral RNA as a template for translation or RNA replication. We propose that after viral entry, the genomic RN A interacts with translation initiation factors to begin protein synthesi s. Once a critical concentration of viral proteins is reached, $3 C D$ binds to the cloverleaf RNA, shuts down viral translation and promotes negative-strand synthesis.

We examined the effects of mutations in the $3 C D$ binding site in the cloverleaf or in the RNA-binding domain in 3CD on translation and negative-strand RNA synthesis. The results showed that the mutated viral RNAs, while translating more efficiently than wild type, do not accumulate negative-strand RNA (Fig. 6). This phenotype could result from the inability of these mutants to shut down translation, as predicted by our model. However, on the basis of the dramatic effect on negative-strand synthesis, it seems more likely that the cloverleaf participates in both repression of translation and initiation of RN A synthesis.

The cloverleaf structure was originally described as an element required for positive-strand RNA synthesis. This conclusion was drawn from the study of mutants with defects either in $3 C D$ or in the cloverleaf that debilitated complex formation, which reduced the ratio of positive to negative-strand RNA accumulated in infected cells (A ndino et al . 1990a). In that previous study, we did not analyze nonviable mutants (unable to form 3CD-cloverleaf complexes) because of the lack of a sensitive method to study RNA synthesis. Here, using a novel assay that allows us to measure negative-strand synthesis independently of positive-strand amplification, we found that mutations that completely abrogate binding of $3 C D$ to the cloverleaf impaired negativestrand synthesis.

It is possible that the defect on positive-strand synthesis detected previously was a consequence of a primary effect on negative-strand synthesis. On the other hand, it could be that, although, the interaction of the cloverleaf with $3 C D$ is required for both initiation of positive- and negative-strand synthesis, each process has a different degree of dependence on complex formation. Thus, a partial defect in ribonucleoprotein complex formation could have a more profound effect on positive-strand than on negative-strand synthesis, resulting in the decreased ratio of positive to negative strands observed.

Repression of viral translation by the binding of $3 C D$ to the cloverleaf RNA

Two sets of experiments presented in this report demonstrate that the binding of $3 C D$ to stem-loop $D$ of the cloverleaf RNA represses viral translation. First, we show that providing an excess of $3 C D$ in trans specifically inhibits poliovirus translation without interfering with cap-dependent translation (Figs. 2 and 3). Second, we examined the effect of $3 C D$ in cis produced by PolioLuC RNA replicons. Mutations either in 3CD or the $3 C D$-binding site of the cloverleaf, resulted in an increase of the level of viral transl ation compare to those of wild type (Figs. 4 and 6).

In addition, we demonstrate that the cloverl eaf RNA is involved in the positive regulation of viral translation. We show that the interaction of PCBP with stem-loop B of the cloverleaf enhances translation 10-fold (Fig. 4). This result is in agreement with recent studies that showed that PCBP is required for efficient poliovirus translation in HeLa cells and oocytes (Blyn et al. 1996, 1997; Gamarnik and Andino 1997; Parsley et al. 1997). Furthermore, there is increasing evidence that PCBP participates in translational control of cellular mRNAs (Holcik and Liebhaber 1997). PCBP is a component of an RNP complex that forms at the $3^{\prime}$ UTR of the human $\alpha$-globin mRN A and determines its stability (Kiledjian et al. 1995). Also, PCBP appears to be responsible for translational silencing of the 15-lipoxigenase mRNA (Ostareck et al. 1997).

The molecular mechanism by which PCBP participates in cap-independent translation remains unknown. Perhaps the binding of PCBP to the viral 5' UTR mediates interactions between the viral RNA and the trans- 
Iation machinery during the internal entry of ribosomes. How could $3 C D$ repress viral translation? It is possible that the binding of $3 C D$ to the cloverleaf alters the interaction of PCBP with this RN A element, which could interfere with the ability of PCBP to promote translation. Thus, the elucidation of the role of PCBP and $3 C D$ in the regulation of viral translation may al so clarify celIular pathways of translational control.

In addition, other viral and cellular factors may participate in the regulation of viral translation. For instance, it has been showed that the viral protein $3 A B$ interacts in solution with $3 C D$ and that the complex $3 A B / 3 C D$ tightly binds to the cloverleaf (Harris et al. 1994). The relevance of this interaction in the regulation of viral translation and RNA replication warrants study.

\section{Cell compartmentalization and translational control}

Given that viral translation must stop to allow RNA synthesis to proceed, it is intriguing that viral protein synthesis in infected cells continues for several hours after RNA replication has already started (Levintow 1974). Poliovirus RN A is synthesized on membrane-associated structures. It has been speculated that membrane compartmentalization may sequester the replication machinery from the rest of the cytoplasm, thereby providing an adequate environment for RNA synthesis (Caliguiri and Tamm 1969; Bienz et al. 1987; Irurzun et al. 1992). According to our model, the local 3CD concentration in a given compartment could determine whether translation or replication will be favored. Can this compartmental ization maintain two separate pools of genomic RN As, one used only for translation and the other for RNA replication? Previous experiments suggested that this is not the case. Viral RNA replication depends on translation of the genome in cis, that is, a particular viral genome must be used first as a template for translation to become competent for RN A synthesis (N ovak and Kirkegaard 1994). Therefore, each molecule of viral RNA must be used as a template for both processes and regulation of the use of the RNA template would be need throughout the entire replicative cycle.

\section{Control of translation and RNA replication}

in positive-stranded RNA viruses

In the proposed model, the repression of viral translation must ensure that all viral proteins required for RN A replication have been produced in sufficient quantities. Poliovirus proteins are expressed as part of a large polyprotein. Thus, each individual polypeptide accumulates in equimolar concentrations and, in principle, could act as a translation shut-off factor. Our results show that 3CD, the precursor of the poliovirus RN A polymerase, inhibits viral translation. Interestingly, the RNA phage $\mathrm{Q} \beta$ uses the interaction of its RNA polymerase with Shine-Dalgarno sequences to control transl ation of the core protein (Kolakofsky and Weissmann 1971; Weber et al. 1972; Meyer et al. 1981), suggesting that animal RNA viruses and bacterial phages might use similar mechanisms to down-regulate translation.

Could this strategy be used by other eukaryotic RN A viruses? The entire poliovirus IRES can be repl aced with corresponding sequences of different members of the $\mathrm{Pi}$ cornaviridae family such as coxsackievirus B3, rhinovirus 14 , mengovirus, encephal omyocarditis virus, without major consequences for viral replication (Alexander et al. 1994; Rohll et al. 1994). Moreover, the same sequences can be replaced by the IRESs of other positivestranded RNA viruses such as hepatitis C virus, a member of the Flaviviridae family (Lu and Wimmer 1996). These observations suggest that the mechanisms and factors that control the switch from translation to RN A replication in these viruses have been conserved. Furthermore, it is reasonable to speculate that even for viruses with capped genomic positive-stranded RNAs, translation and negative-strand synthesis are antagonistic. For these viruses however, a different mechanism for translational control is probably used. In conclusion, the results presented here provide insight into a general strategy by which positive-stranded RNA viruses might use common RNA structures for translation and initiation of RNA replication to coordinate these two processes.

\section{Materials and methook}

HeLa cell transfections, infections, and cytoplasmic extract preparation

To test the translation efficiencies of wild-type and mutant Polio-Luc RN As, 100-mm dishes containing $~ 3 \times 10^{6} \mathrm{HeLa}$ cells were trypsinized and transfected with $10 \mu \mathrm{g}$ of in vitro transcribed RNA per plate by standard electroporation procedures. After $2 \mathrm{hr}$ of incubation at $37^{\circ} \mathrm{C}$, cells were washed with PBS, scraped from the plates, and lysed in $200 \mu$ l of Iysis buffer (Promega). Luciferase activity was measured in $10 \mu \mathrm{l}$ of extract with a luciferase system as recommended by the manufacturer (Promega) and quantified by use of an Optocomp I luminometer.

For poliovirus infection, $4 \times 10^{8} \mathrm{HeLa}$ cells grown in suspension were mock infected or infected with wild-type poliovirus at a multiplicity of infection of 30 pfu per cell. After absorption at room temperature for $30 \mathrm{~min}, 1$ liter of fresh medium was added, and the cultures were incubated at $37^{\circ} \mathrm{C}$ for $6 \mathrm{hr}$. Then, the cells were collected by centrifugation and washed three times with cold PBS. The pellet was resuspended in 2 vols of hypotonic buffer (20 mM HEPES at pH 7.4, $10 \mathrm{~mm} \mathrm{KCl}, 1.5 \mathrm{~mm}$ $\mathrm{Mg}\left(\mathrm{CH}_{3} \mathrm{CO}_{2}\right)_{2}, 2 \mathrm{~mm}$ dithiothreitol), incubated on ice for 20 $\mathrm{min}$, and homogenized by 20 strokes with a glass Dounce homogenizer. A postnuclear supernatant was obtained by centrifugation at $5000 \mathrm{~g}$ for $10 \mathrm{~min}$ at $4^{\circ} \mathrm{C}$. This supernatant was submitted to a second centrifugation $(15,000 \mathrm{~g}$ for $20 \mathrm{~min}$ ) to obtain S10 cytoplasmic extract. Further centrifugation yiel ded a postribosomal supernatant (S100) and a ribosomal pellet (P100) as described previously (Brown and Ehrenfeld 1979). The fractions were supplemented with $5 \%$ glycerol and stored at $-70^{\circ} \mathrm{C}$.

Partially purified S100 fractions were depleted of 3CD by use of a biotinylated cloverleaf RN A. The cloverleaf RNA was transcribed in vitro in the presence of limiting concentrations of biotin-16-UTP to incorporate 2-3 biotinylated nucleotides per molecule of RNA. Thirty micrograms of this RNA was incubated with $40 \mu$ of streptavidin beads and washed five times 
with PBS. Finally, $200 \mu$ of the partially purified fraction containing $3 C D$ was incubated with the beads for $1 \mathrm{hr}$ on ice, and, after centrifugation, the supernatant was injected directly into Xenopus oocytes or analyzed by Western blotting with anti3CD antibodies. The control sample was treated under the same conditions, except that biotin was not added during transcription of the cloverleaf RNA.

\section{Microinjections in Xenopus oocytes}

Oocytes were surgically isolated and enzymatically defolliculated as described previously (Gamarnik and Andino 1996). Manual ly sorted stage VI oocytes were injected with $20 \mathrm{nl}$ of in vitro-transcribed Polio-Luc or Cap-Luc RN A $(1 \mu \mathrm{g} / \mu \mathrm{l})$ and $20 \mathrm{nl}$ of the HeLa cell fraction, to provide the cellular factor essential for poliovirus translation in oocytes (PTF; Gamarnik and Andino 1996). Expression of 3C, 3D, 3CD, or GFP proteins in Xenopus oocytes was carried out by injection of a capped RNA encoding for the respective protein. The capped RNAs were obtained by in vitro-transcription with $\mathrm{T} 7$ polymerase. Injected oocytes were incubated for $15 \mathrm{hr}$ at $17^{\circ} \mathrm{C}$ and injected a second time with $40 \mathrm{ng}$ of Polio-Luc RNA or Cap-Luc RNA together with $20 \mathrm{nl}$ of uninfected S10 HeLa cell extract to provide PTF. The effect of decoy cloverleaf RN As (wild-type, loop B mutant, and loop $D$ mutant) on viral translation was determined by coinjection of $10 \mathrm{nl}$ of decoy RN A $(3 \mu \mathrm{g} / \mu \mathrm{l})$ or buffer control with 20 $\mathrm{nl}$ of Polio-Luc RNA together with $20 \mathrm{nl}$ of S10 HeLa cell proteins. For measurement of luciferase expression, 10 oocytes were lysed in Iysis buffer ( $20 \mu \mathrm{l}$ per oocyte; Promega) and centrifuged for $5 \mathrm{~min}$ at $10,000 \mathrm{~g}$. The supernatant $(5 \mu \mathrm{l})$ was assayed by use of a luciferase system as described above.

To analyze negative-strand RNA synthesis, in vitro-transcribed ${ }^{32} \mathrm{P}$-labeled poliovirus RN A (30 ng) was microinjected into Xenopus oocytes together with $100 \mathrm{ng}$ of S10 HeLa cell proteins. Oocytes were incubated at $30^{\circ} \mathrm{C}$ in a media containing $50 \mu \mathrm{g} / \mathrm{ml}$ of actinomycin D (Buller and White 1990). Thirty oocytes were lysed at various times in $400 \mu \mathrm{l}$ of TEN SK buffer $(50 \mathrm{~mm}$ Tris- $\mathrm{HCl}$ at $\mathrm{pH} 7.5,5 \mathrm{~mm}$ EDTA, $100 \mathrm{~mm} \mathrm{NaCl}, 1 \%$ SDS, $200 \mu \mathrm{g} / \mathrm{ml}$ proteinase $\mathrm{K}$ ), incubated at $37^{\circ} \mathrm{C}$ for $1 \mathrm{hr}$, extracted with phenol-chloroform, and precipitated with ethanol. Samples were resuspended in $50 \mu \mathrm{l}$ of TE, treated with DN ases and analyzed by electrophoresis through $1 \%$ native agarose gels and autoradiographed. rRN A, visualized by ethidium bromide, was used as an internal control for RN A extraction. Crude replication complexes were prepared as described previously ( $T$ akeda et al. 1986).

To analyze the presence of Vpg-linked RNA, 60 oocytes were injected with in vitro-transcribed ${ }^{32} \mathrm{P}$-labeled poliovirus RNA and processed as described above with the exception that proteinase $\mathrm{K}$ was omitted in the TEN SK buffer and the incubation at $37^{\circ} \mathrm{C}$ was not performed. After phenol-chloroform extraction and ethanol precipitation (to remove noncoval ently bound $\mathrm{Vpg}$ ), the samples were diluted to $0.5 \mathrm{ml}$ with NE buffer $(50 \mathrm{~mm}$ Tris- $\mathrm{HCl}$ at $\mathrm{pH} 7.4,100 \mathrm{~mm} \mathrm{NaCl}, 0.02 \% \mathrm{NP}-40$ ), plus $10 \mu \mathrm{l}$ of preimmune or anti- $\mathrm{Vpg}$ antibodies, and the mixture was incubated for $1 \mathrm{hr}$ on ice. Then, $50 \mu \mathrm{l}$ of protein A-agarose (Boehringer) equilibrated in NE buffer was added, and the mixture was incubated for $1 \mathrm{hr}$ rocking at $4^{\circ} \mathrm{C}$. After incubation, the samples were centrifuged at maximum speed for $10 \mathrm{sec}$, and the beads were washed four times with $1 \mathrm{ml}$ of NE buffer. After the final wash, the beads were resuspended in NE buffer containing $1 \%$ SDS and removed by centrifugation. Ten micrograms of glycogen was added, and the samples were phenol extracted, ethanol precipitated, analyzed through $1 \%$ native agarose gels and autoradiographed.

For N orthern blot analysis, 200 oocytes were injected with unlabeled poliovirus RNA ( $30 \mathrm{ng}$ ) together with $100 \mathrm{ng}$ of S10 HeLa cell proteins. Oocytes were incubated at $30^{\circ} \mathrm{C}$ for $20 \mathrm{hr}$, lysed in TEN SK buffer and incubated for $1 \mathrm{hr}$ at $37^{\circ} \mathrm{C}$. Then, the samples were extracted with phenol-chloroform, precipitated with ethanol, treated with DN ases, separated on a denaturing agarose gel, transferred to a nylon filter, and hybridized with a specific probe complementary to the poliovirus negative-strand RNA. As a control an infected HeLa cell extract was treated under the same conditions as the oocyte extracts.

\section{Translation/replication}

Reticulocyte translation lysates were obtained from Promega. Thirty-five microliters of lysate was supplemented with $4 \mu \mathrm{g}$ of S10 HeLa cell extract, a mixture of the 20 amino acids at $50 \mu \mathrm{m}$ final concentration, and $4 \mu \mathrm{l}$ of buffer $3 \mathrm{D}(50 \mathrm{~mm} \mathrm{HEPES}$ at $\mathrm{pH}$ 8.0, $4 \mathrm{~mm}$ DTT, $\left.3 \mathrm{~mm} \mathrm{Mg}\left(\mathrm{CH}_{3} \mathrm{CO}_{2}\right)_{2}, 5 \mu \mathrm{M} \mathrm{ZnCl}{ }_{2}, 0.1 \% \mathrm{NP}-40\right)$. One microliter of Polio-Luc RNA was used as a template. A primer complementary to the $3^{\prime}$ UTR (CAATCCAATTC$\mathrm{GACT}$ ) was anneal ed to the template by $5 \mathrm{~min}$ of incubation at $60^{\circ} \mathrm{C}$. The translation reaction was initiated by incubating the mixture at $30^{\circ} \mathrm{C}$ with or without cycloheximide. After $15 \mathrm{~min}$ of incubation to allow for translation to begin, one-half of the translation reaction was combined with ATP, GTP, and CTP $\left.(0.25 \mathrm{~mm}),{ }^{32} \mathrm{P}\right]$ UTP $(0.3 \mu \mathrm{Ci}, 25 \mu \mathrm{m}$ final concentration), and 3 $\mu \mathrm{l}$ of a partially purified poliovirus polymerase. Both reactions (translation and RNA replication) were allowed to proceed at $30^{\circ} \mathrm{C}$ for $90 \mathrm{~min}$; samples were removed every $15 \mathrm{~min}$, nucleotide incorporation into RN A was determined by TCA precipitation, and translation was monitored by luciferase activity produced over time. Poliovirus polymerase was obtained from poliovirus-infected HeLa cells as described (Hey et al. 1986) and partially purified by means of a HiTrapQ chromatography (Pharmacia).

\section{Acknowledgments}

We are grateful to Judith Frydman, Alan Frankel, Elizabeth Blackburn, and members of Andino's laboratory particularly to $\mathrm{N}$ ina Boddeker, Shane Crotty, and Debbie Silvera for their useful comments on the manuscript; and Amy Corder for graphics. This work was supported by funds provided by the Department of Microbiology and Immunology, University of California, San Francisco and U.S. Public Health Service grant AI40085 to R.A.

The publication costs of this article were defrayed in part by payment of page charges. This article must therefore be hereby marked "advertisement" in accordance with 18 USC section 1734 solely to indicate this fact.

\section{References}

Alexander, L., H.H. Lu, and E. Wimmer. 1994. Polioviruses containing picornavirus type 1 and/or type 2 internal ribosomal entry site elements: Genetic hybrids and the expression of a foreign gene. Proc. Natl. Acad. Sci. 91: 1406-1410.

Andino, R., G.E. Rieckhof, and D. Baltimore. 1990a. A functional ribonucleoprotein complex forms around the $5^{\prime}$ end of poliovirus RN A. Cell 63: 369-380.

Andino, R., G.E. Rieckhof, D. Trono, and D. Baltimore. 1990b. Substitutions in the protease ( $3 \mathrm{C}$ pro) gene of poliovirus can suppress a mutation in the $5^{\prime}$ noncoding region. J. Virol. 64: 607-612.

Andino, R., G.E. Rieckhof, P.L. Achacoso, and D. Baltimore. 1993. Poliovirus RNA synthesis utilizes an RNP complex 
formed around the $5^{\prime}$-end of viral RNA. EMBO J. 12: 35873598.

Barton, D.J. and J.B. Flanegan. 1993. Coupled translation and replication of poliovirus RNA in vitro: Synthesis of functional 3D polymerase and infectious virus. J. Virol. 67: 822831.

Belsham, G.J. and N. Sonenberg. 1996. RNA-protein interactions in regulation of picornavirus RN A translation. Microbiol. Rev. 60: 499-511.

Bienz, K., D. Egger, and L. Pasamontes. 1987. Association of polioviral proteins of the $\mathrm{P} 2$ genomic region with the viral replication complex and virus-induced membrane synthesis as visualized by electron microscopic immunocytochemistry and autoradiography. Virology 160: 220-226.

Blyn, L.B., K.M. Swiderek, O. Richards, D.C. Stahl, B.L. Semler, and E. Ehrenfeld. 1996. Poly $(r C)$ binding protein 2 binds to stem-loop IV of the poliovirus RNA 5' noncoding region: Identification by automated liquid chromatography-tandem mass spectrometry. Proc. Natl. Acad. Sci. 93: 11115-11120.

Blyn, L.B., J.S. Towner, B.L. Semler, and E. Ehrenfeld. 1997. Requirement of poly $(\mathrm{rC})$ binding protein 2 for translation of poliovirus RNA. J. Virol. 71: 6243-6246.

Borman, A.M., F.G. Deliat, and K.M. Kean. 1994. Sequences within the poliovirus internal ribosome entry segment control viral RNA synthesis. EMBO J. 13: 3149-3157.

Brown, B.A. and E. Ehrenfeld. 1979. Translation of poliovirus RNA in vitro: Changes in cleavage pattern and initiation sites by ribosomal salt wash. Virology 97: 396-405.

Buller, A.L. and M.M. White. 1990. Functional acetylcholine receptors expressed in Xenopus oocytes after injection of Torpedo beta, gamma, and delta subunit RN As are a consequence of endogenous oocyte gene expression. Mol. Pharmacol. 37: 423-428.

Caliguiri, L.A. and I. Tamm. 1969. Membranous structures associated with translation and transcription of poliovirus RN A. Science 166: 885-886.

Chen, C.Y. and P. Sarnow. 1995. Initiation of protein synthesis by the eukaryotic translational apparatus on circular RNAS. Science 268: 415-417.

Collis, P.S., B.J. O'Donnell, D.J. Barton, J.A. Rogers, and J.B. Flanegan. 1992. Replication of poliovirus RNA and subge nomic RNA transcripts in transfected cells. J. Virol. 66: 6480-6488.

Ehrenfeld, E. and B.L. Semler. 1995. Anatomy of the poliovirus internal ribosome entry site. Curr. Top. Microbiol. Immunol. 203: 65-83.

Flanegan, J.B., R.F. Petterson, V. Ambros, N.J. Hewlett, and D. Baltimore. 1977. Covalent linkage of a protein to a defined nucleotide sequence at the 5 '-terminus of virion and replicative intermediate RNAs of poliovirus. Proc. Natl. Acad. Sci. 74: 961-965.

Gamarnik, A.V. and R. Andino. 1996. Replication of poliovirus in Xenopus oocytes requires two human factors. EMBO J. 15: 5988-5998.

- - - 1997. Two functional complexes formed by $\mathrm{KH}$ domain containing proteins with the $5^{\prime}$ noncoding region of poliovirus RNA. RNA 3: 882-892.

Harris, K.S., W. Xiang, L. Alexander, W.S. Lane, A.V. Paul, and E. Wimmer. 1994. Interaction of poliovirus polypeptide $3 C D$ pro with the $5^{\prime}$ and $3^{\prime}$ termini of the poliovirus genome. Identification of viral and cellular cofactors needed for efficient binding. J. Biol. Chem. 269: 27004-27014.

Hellen, C.U., G.W. Witherell, M. Schmid, S.H. Shin, T.V. Pestova, A. Gil, and E. Wimmer. 1993. A cytoplasmic 57$\mathrm{kDa}$ protein that is required for translation of picornavirus RNA by internal ribosomal entry is identical to the nuclear pyrimidine tract-binding protein. Proc. Natl. Acad. Sci. 90: 7642-7646.

Hey, T.D., O.C. Richards, and E. Ehrenfeld. 1986. Synthesis of plus- and minus-strand RNA from poliovirion RNA template in vitro. J. Virol. 58: 790-796.

Holcik, M. and S.A. Liebhaber. 1997. Four highly stable eukaryotic mRN As assemble $3^{\prime}$ untranslated region RNA- protein complexes sharing cis and trans components. Proc. Natl. Acad. Sci. 94: 2410-2414.

Irurzun, A., L. Perez, and L. Carrasco. 1992. Involvement of membrane traffic in the replication of poliovirus genomes: Effects of brefeldin A. Virology 191: 166-175.

Jackson, R.J. and A. Kaminski. 1995. Internal initiation of translation in eukaryotes: The picornavirus paradigm and beyond. RNA 1: 985-1000.

Jang, S.K., H.G. Krausslich, M.J. Nicklin, G.M. Duke, A.C. Palmenberg, and E. Wimmer. 1988. A segment of the $5^{\prime}$ nontranslated region of encephal omyocarditis virus RN A directs internal entry of ribosomes during in vitro translation. J. Virol. 62: 2636-2643.

Johnson K. and P. Sarnow. 1995. Viral RN A synthesis. In Human enterovirus infections (ed. H. Rotbart), pp. 95-112. ASM, Washington, DC.

Kiledjian, M., X. Wang, and S.A. Liebhaber. 1995. Identification of two $\mathrm{KH}$ domain proteins in the al pha-globin mRN P stability complex. EMBO J. 14: 4357-4364.

Kolakofsky, D. and C. Weissmann. 1971. Q replicase as repressor of Q RN A-directed protein synthesis. Biochim. Biophys. Acta. 246: 596-599.

Kuge, S., I. Saito, and A. N omoto. 1986. Primary structure of poliovirus defective-interfering particle genomes and possible generation mechanisms of the particles. J. Mol. Biol. 192: 473-487.

Levintow, L. 1974. The reproduction of picornaviruses. In Comprehensive virology (ed. H. Fraenkel-Conrat and R. Wagner), pp. 109-164. Plenum Press, N ew York, NY.

Lu, H.H. and E. Wimmer. 1996. Poliovirus chimeras replicating under the translational control of genetic elements of hepatitis $C$ virus reveal unusual properties of the internal ribosomal entry site of hepatitis C virus. Proc. Natl. Acad. Sci. 93: 1412-1417.

Mathews, M.B. 1996. Interaction between viruses and the cellular machinery for protein synthesis. In Translational control (ed. J.W. Hershey, M.B. Mathews, and N. Sonenberg), pp. 505-548. Cold Spring Harbor Laboratory Press, Cold Spring Harbor, NY.

Meerovitch, K., Y.V. Svitkin, H.S. Lee, F. Lejbkowicz, D.J. Kenan, E.K. Chan, V.I. Agol, J.D. Keene, and N. Sonenberg. 1993. La autoantigen enhances and corrects aberrant translation of poliovirus RNA in reticulocyte lysate. J. Virol. 67: 3798-3807.

Meyer, F., H. Weber, and C. Weissmann. 1981. Interactions of Q beta replicase with Q beta RN A. J. Mol. Biol. 153: 631-660.

Meyer, K., A. Petersen, M. N iepmann, and E. Beck. 1995. Interaction of eukaryotic initiation factor elF-4B with a picornavirus internal translation initiation site. J. Virol. 69: 28192824.

Molla, A., A.V. Paul, and E. Wimmer. 1991. Cell-free, de novo synthesis of poliovirus. Science 254: 1647-1651.

N ovak, J.E. and K. Kirkegaard. 1994. Coupling between genome translation and replication in an RN A virus. Genes \& Dev. 8: 1726-1737.

Ostareck, D.H., A. Ostareck-Lederer, M. Wilm, B.J. Thiele, M. Mann, and M.W. Hentze. 1997. mRNA silencing in erythroid differentiation: hnRN P K and hnRN P El regulate 15lipoxygenase translation from the $3^{\prime}$ end. Cell 89: 597-606. 


\section{Gamamik and Andino}

Parsley, T.B., J.S. Towner, L.B. Blyn, E. Ehrenfeld, and B.L. Semler. 1997. Poly ( $r C$ ) binding protein 2 forms a ternary complex with the $5^{\prime}$ - terminal sequences of poliovirus RN A and the viral 3CD proteinase. RNA 3: 1124-1134.

Pelletier, J., G. Kaplan, V.R. Racaniello, and N . Sonenberg. 1988. Cap-independent translation of poliovirus mRNA is conferred by sequence el ements within the $5^{\prime}$ noncoding region. Mol. Cell. Biol. 8: 1103-1112.

Pestova, T.V., C.U. Hellen, and I.N. Shatsky. 1996. Canonical eukaryotic initiation factors determine initiation of translation by internal ribosomal entry. Mol. Cell. Biol. 16: 68596869.

Pettersson, R.F., V. Ambros, and D. Baltimore. 1978. Identification of a protein linked to nascent poliovirus RN A and to the polyuridylic acid of negative-strand RNA. J. Virol. 27: 357365.

Pogue, G.P., C.C. Huntley, and T.C. Hall. 1994. Common replication strategies emerging from the study of diverse groups of positive-strand RN A viruses. Arch. Virol. Suppl. 9: 181194.

Roehl, H.H., T.B. Parsley, T.V. Ho, and B.L. Semler. 1997. Processing of a cellular polypeptide by $3 C D$ proteinase is re quired for poliovirus ribonucleoprotein complex formation. J. Virol. 71: 578-585.

RohlI, J.B., N. Percy, R. Ley, D.J. Evans, J.W. Almond, and W.S. Barclay. 1994. The $5^{\prime}$-untranslated regions of picornavirus RN As contain independent functional domains essential for RN A replication and translation. J. Virol. 68: 4384-4391.

Shiroki, K., T. Ishii, T. Aoki, M. Kobashi, S. Ohka, and A. N omoto. 1995. A new cis-acting element for RNA replication within the $5^{\prime}$ noncoding region of poliovirus type 1 RNA. J. Virol. 69: 6825-6832.

Simoes, E.A. and P. Sarnow. 1991. An RN A hairpin the extreme $5^{\prime}$ end of the poliovirus RNA genome modulates viral translation in human cells. J. Virol. 65: 913-921.

Takeda, N., R.J. Kuhn, C.F. Yang, T. Takegami, and E. Wimmer. 1986. Initiation of poliovirus plus-strand RN A synthesis in a membrane complex of infected HeLa cells. J. Virol. 60: 4353.

Trono, D., J. Pelletier, N. Sonenberg, and D. Baltimore. 1988. Translation in mammalian cells of a gene linked to the poliovirus 5' noncoding region. Science 241: 445-448.

Weber, H., M.A. Billeter, S. Kahane, C. Weissmann, J. Hindley, and A. Porter. 1972. Molecular basis for repressor activity of Q replicase. Nat. New. Biol. 237: 166-170. 


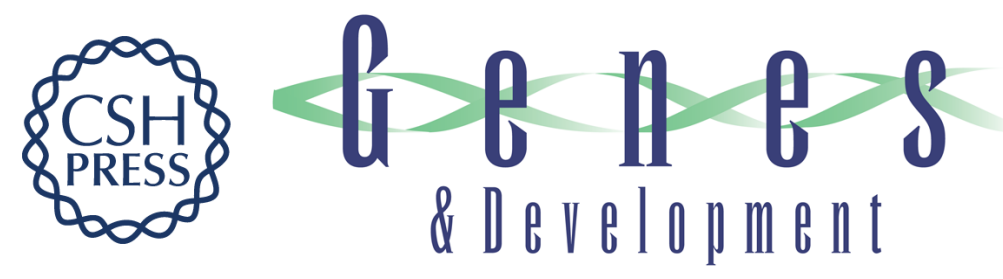

\section{Switch from translation to RNA replication in a positive-stranded RNA virus}

Andrea V. Gamarnik and Raul Andino

Genes Dev. 1998, 12:

Access the most recent version at doi:10.1101/gad.12.15.2293

References This article cites 48 articles, 32 of which can be accessed free at: http://genesdev.cshlp.org/content/12/15/2293.full.html\#ref-list-1

License

Email Alerting

Receive free email alerts when new articles cite this article - sign up in the box at the top Service right corner of the article or click here.

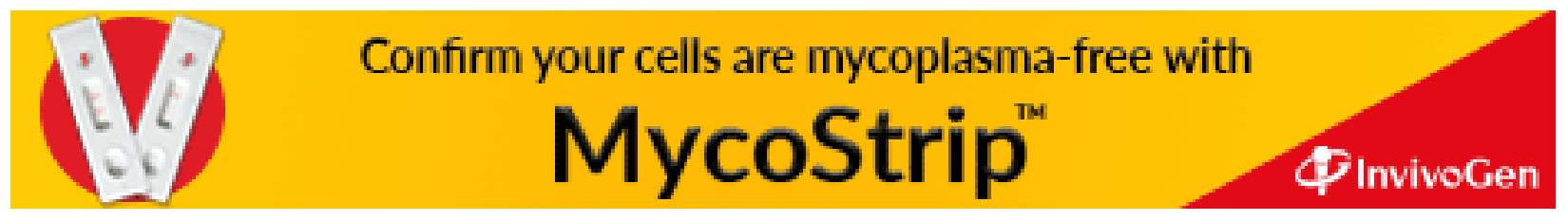

